\title{
Family Empowerment to Prevent Dengue Hemorrhagic Fever (DHF) in Dataran Tinggi, Binjai, Sumatera Utara
}

\author{
Nurmaini ${ }^{1}$, Namora Lumongga Lubis ${ }^{2}$ \\ ${ }^{I}$ Public Health Faculty, University of Sumatera Utara, Indonesia \\ nurmainik@yahoo.com \\ ${ }^{2}$ Public Health Faculty, University of Sumatera Utara, Indonesia \\ namoralubis041072@gmail.com
}

\begin{abstract}
Dengue Hemorrhagic Fever (DHF) is an infectious disease and has been endemic to many areas in Indonesia. Its cases have increased rapidly every year. This research focused on the family empowerment to prevent DHF. It was a qualitativeexploratory research by doing in-depth interviews, observation and Focus Group Discussion (FGD) involving 25 informants. It is found that there are 3 (three) main concerns obtained through observation and in-depth interview, they are: 1) The participation of family in eradication of mosquito larvae, 2) The breeding sites of Aedes aegypti, and 3) The information about DHF. In addition, there are 3 (three) main problems discovered by performing FGD, namely: 1) Population density 2) Less awareness of the society, 3) Lack of community participation. Moreover, the training for health volunteers can enhance their knowledge about DHF and giving counseling to the family also can be an alternative to empower the family's participation. It shows that problems related DHF demands appropriate and quick actions. Therefore, the people, the local government and Health Department must work together and support each other to prevent DHF by empowering the families and health volunteers.
\end{abstract}

Keywords - Aedes aegypti, DHF, family empowerment

\section{INTRODUCTION}

The number of infectious diseases has rapidly increased in recent years. Some of its leading causes are widespread deforestation, developing irrigation construction, ineffective vector control measure, excessive population density, low sanitation as well as low public awareness on healthy life. One of infectious diseases which still has high frequency of incidence and is classified as Extraordinary Incidence $($ KLB $=$ Kejadian Luar Biasa) is Dengue Hemorraghic Fever (DHF).

Severe Dengue (also known as Dengue Hemorrhagic Fever) is a viral disease transmitted by mosquitoes (Aedes aegypti) in tropical and subtropical regions of the world [3].
WHO (2016) updated that DHF was first recognized in the 1950s during dengue epidemics in Philippines and Thailand. Today, it affects most of Asian and Latin American countries and has become a leading cause of hospitalization and death among children and adults in these regions [10].

In Indonesia, it was recorded that in 2009, the total number of DHF cases was 158,912 with 1,420 deaths, Incident Rate (IR): 68.22 per 100,000 inhabitants and the Case Fatality Rate (CFR) was $0.89 \%$. In 2010, there were 156, 086 cases with 1,358 deaths, IR 65.70 per 100,000 inhabitants and CFR was $0.87 \%$. In 2011 to October, it was 49,486 with 403 deaths, IR 20.83 per 100,000 inhabitants and CFR $0.81 \%$ [1].

Based on the record, every year, DHF cases occur in Sumatera Utara. The number of infected and dead patients for the last decade (September 19992009) has increased significantly; in 2007 with 4,195 cases and in 2008 with 4, 454 cases. The last five years data (2004-2008) showed that the average of IR was in the range of 8.79-33.28 per 100,000 inhabitants while the average of CFR was in the range of 0.91 to $2.20 \%$ [2].

In 2010, it was recorded that in Binjai, there were 145 people infected with IR was 18.1 and CFR was 0\%. In 2011, it also recorded an increase in DHF cases; 158 people infected and 3 persons died. These data indicate that the number of DHF patients increases each year.

There are many factors leading to high rates of IR and CFR. One of them is the large number of breeding places as the vector which triggers the number of lots. It implies that the vector must be 
reduced. One of effective ways can be done is by breaking the cycle of mosquitoes through mosquito eradication ( $P S N=$ Pemberantasan Sarang Nyamuk). Therefore, the actions to eradicate mosquitoes need to be developed since $P S N$ has been proven to reduce dengue cases in many countries [5]. Moreover, there is a correlation between PSN-DHF with the existence of larva. If there is no extermination on breeding places of Aedes aegypti, the existence of these larvae will become a risk factor for people to be infected [4].

The Ministry of Health determined 5 (five) main actions to control DHF, they are: 1) recognizing the patient infected by DHF immediately and treating him based on regular procedures, 2) breaking the transmission chain of the vector (larvae and adult mosquitoes), 3) building a partnership in groups, 4) empowering the community through PSN program, and 5) improving the professionalism of program managers.

As one of main actions proposed by the government, $P S N$ program is familiar with its ' $3 M$ ' slogan; draining (menguras), covering (menutup) and burying (mengubur). It has been done since 1992 but in 2000, it was developed with $3 M$-plus; draining (menguras), covering (menutup), recycling (mendaur ulang) and applying appropriate insecticides to water storage outdoor containers or insect repellent to skin. However, these efforts have not shown the desired results because every year the morbidity and mortality rates increase significantly [6].

It is not easy to overcome that problem. It certainly involves many aspects; physical, social, cultural, educational, economic and so on, which will have an impact on the whole community. It means a sustainable development is required in order to improve the welfare of society. However, there must be pros and cons in its progression. With the barriers and the crisis on the country, various problems may arise, for example the difficulty of people to use various facilities such as limited health services. Therefore, community-based may be one alternative to improve the standard of living [4]. One of those services is the development of society. Community development is widely used to improve lives and empower the community.
Family as the smallest part of a community has a very influential power in supporting any policies in the community which is known as 'family empowerment'. Family empowerment focuses on perceiving families as active agents interacting with the larger community [7]. It means that families can be empowered to overcome the problems occurred, especially DHF problem. Thus, it is so important for a family to know more information about DHF that every member of family can be an agent of change to prevent the spread of DHF since there is a significant correlation between the respondents' knowledge and DHF [9].

\section{RESEARCH METHODOLOGY}

This research used qualitative-exploratory method conducted at Dataran Tinggi, Binjai, Sumatera Utara as it has the highest DHF case of 12 sub-districts which are endemic to DHF among 37 sub-districts existed. It involved 25 informants by applying snowball sampling technique. Most of respondents are around 30-40 years old (16 persons), graduated from high school (8 persons) and have worked (18 persons). Data were collected in 3 (three) ways: 1) In-depth interviews, (2) Observation of breeding places, and (3) Focus Group Discussion (FGD).

\section{FINDINGS AND DISCUSSIONS}

Based on the research done, it is found that:

1) There are 3 (three) main concerns obtained through observation and in-depth interview, they are: 1) The participation in eradication of mosquito larvae, 2) The breeding sites of Aedes aegypti, and 3) The information about DHF.

2) There are also 3 (three) main problems discovered by performing FGD, namely: 1) Population density, 2) Less awareness of the society about the environment, 3) Lack of community's participation

3) The training performed for health volunteers can enhance their knowledge about DHF to empower the family's participation to prevent DHF.

4) Giving counseling also can be an alternative to empower the family's participation to prevent DHF. 


\section{A. Doing Observation and In-Depth Interview}

Based on the results of observation and in-depth interview, it is found that most of the people have not received information about dengue from health volunteers. Therefore, the volunteers are trained so they will be able to explain about DHF in order to help and save the people around them. They are also must be assisted by health officials from the local Health Department who know more the local health problems, especially the problem of DHF.

In addition, based on the results of observations from 15 informants, it is known that mosquito larvae exist in most of breeding places, either inside or outside of home. As a feedback, they received information that breeding places of larvae should be checked before a week because larvae will be adult mosquitoes within 7-10 days. Breeding places of mosquito larvae also must be destroyed by cleaning up all the places potentially become breeding sites.

Environmental hygiene is also effective to inhibit the breeding of Aedes mosquito for clean water basins are potential for mosquitoes' breeding. The cooperation of all parts is needed to clean up areas inside and outside of home environment in order to prevent and eradicate the spread of mosquitoes' breeding places.

The efforts to control dengue have been made because until now there is no vaccine to heal it so it is important to eradicate the mosquito's larvae or adult mosquitoes. The strategy made by the public to eliminate mosquito's larvae is an effort involving the community, especially families in $P S N$ movement.

\section{B. Performing Focus Group Discussion (FGD)}

There are different opinions obtained from participants on the issue of dengue in the society by performing FGD. However, there are some core problems, they are: first, population density which contributes or as a risk factor for the transmission of DHF. The more densely populated, the easier Aedes transmit the virus from one person to another. Second, less awareness of the society about the environment, for instance, trashed litters which create unhealthy environment. Third, lack of community participation in the eradication of breeding sites of wiggler, where there are many places that can hold water as breeding places of mosquitoes.

\section{Training for Health Volunteers}

Training is held as a form of health education at community level, included recognizing the symptoms of DHF, the ways to help patients with DHF, and so on. Training for the volunteers is performed because they are basically health educators and health educators play important role in behaviour admission process [8].

Health volunteers did pre-test before they got training in order to improve their knowledge about DHF. The result of pre-test showed that the five volunteers had different competences. The first volunteer answered correctly 19 items $(61 \%)$, the second- 22 items (71\%), the third-18 items (58\%), the fourth-17 items (51\%) and the fifth-24 items $(77 \%)$. It means that there are 2 (two) volunteers have low-ranking knowledge, 3 (three) volunteers have medium-ranking knowledge and no one has high-ranking knowledge.

After 3 (three) days-training, the volunteers did post-test in order to re-evaluate their competences. The items to be answered are similar with the pretest. The result of post-test showed that the first volunteer answered correctly 27 items, the second29 items, the third-26 items, the fourth-24 items and the fifth 27 items. It can be inferred that 4 (four) volunteers have high knowledge about DHF and 1 (one) has medium knowledge. It describes that all of them are able to understand the matters given. Overall, it shows that training is an appropriate way to enhance the knowledge of health volunteers about DHF.

Health education is not merely people know about health but the most important thing is they can apply health behaviours. Health is not only knowing or realizing health behaviours but also implementing them in daily life. The people can adopt a healthy life-style so that they will not be infected by various diseases included DHF. Therefore, the community must be provided with the knowledge about DHF to create a better future.

\section{Giving Counselling About DHF}

Health counseling is one of the methods that can be implemented to enhance the people's knowledge and abilities through learning techniques in order to 
change or influence the behaviour of individuals, communities and societies. Its purpose is to provide education about DHF information to the community and implement PSN program by empowering the families. It is expected that they can apply the knowledge obtained to change their attitude and action to improve health level. The enhancement of knowledge about DHF has the effect to increase the community's understanding and participation in prevention of DHF.

The counseling was done directly by facing the people at the research area and using LCD equipped with so attractive pictures (visual) that more people would understand the topics given. The counseling involved two instructors divided in two sessions. Before it was done, the instructors gave some coloured brochures and the topics about DHF. The topics focused on the symptoms, signs, and how the first aid could be performed on patients with DHF. From environmental aspects, the counseling covered the preferred breeding sites of Aedes aegypti mosquito and mosquito's life cycle so that the public will be able to break that cycle.

Various efforts have been made to control the increasing number of DHF cases. Visiting the people's houses, promoting group discussion in the society, involving community groups working in their environment and campaigning through mass or print media in order to reinforce the public awareness are some strategies that can be done to empower the community's participation, especially the family itself.

\section{IV.CONCLUSIONS AND SUGGESTIONS}

There will be more problems occurred related to DHF and it demands appropriate and quick actions. Therefore, the people, the local government and Health Department must work together and support each other to prevent DHF by empowering the families and health volunteers.

\section{REFERENCES}

[1] Aditama, Tjandra Yoga. (2012, May 13). Kematian Akibat DBD Berkurang Tetapi Jumlah Kasus Meningkat. Retrieved from health.detik.com/.../kematian-akibat-dbd-berkuran... -

[2] Candra, Syafei. (2010, March 24). Upaya cegah DBD di Sumut Retrieved from

http://www.waspada.co.id/index.php?option=com_content\&view=artic le \&id=71076:upaya-cegah-dbd-di-sumut\&catid=25: artikel \&Itemid=44

[3] Delaware Health and Social Services. (June, 2011). Frequently Asked Questions. Retrieved form

http://www.dhss.delaware.gov/dph/files/denguefvrfaq.pdf
[4] Ife , Jim \& Frank Tesoriero, (2006). Community Development: Community-Based Alternatives in an Age of Globalization. Pearson Education: Australia

[5] Lucky, Radita Alma. (2014, September). Pengaruh Status Penguasaan Tempat Tinggal dan Perilaku PSN-DBD terhadap Keberadaan Jentik di Kelurahan Sekaran kota Semarang. Unnes Journal of Public Health, 3, 3. Retrieved from http://journal.unnes.ac.id/sju/index.php/ujph

[6] Ministry of Health, Republic of Indonesia. (2016, February 7). Kendalikan DBD dengan PSN $3 M$ Plus. Retrieved from http://www.depkes.go.id/article/view/16020900002/kendalikan-dbddengan-psn-3m-plus.html

[7] Nachsen, Jennnifer S. (2005). Empowerment and Families: Building Bridges between Parents and Professionals, Theory and Research. Journal on Developmental Disabilities, 11, 67 http://citeseerx.ist.psu.edu/viewdoc/download?doi=10.1.1.575.9567\&r ep=rep $1 \&$ type $=$ pdf

[8] Rogers, Everett M. (2005). Diffusion of Innovations. Glencoe Free Press: New York

[9] Santoso., Budiyanto, Anif. (2008, August). Hubungan Pengetahuan, Persepsi, dan Tingkah Laku (PSP) Masyarakat Terhadap Vektor DBD di Kota Palembang Sumatera Selatan. Jurnal Ekologi Kesehatan, 7(2), 732-739. Retrieved from file:///C:/Users/ACER/Downloads/16491153-1-PB.pdf

[10] WHO. (2016, April). Dengue and Severe Dengue. Retrieved from http://www.who.int/mediacentre/factsheets/fs117/en/ 